\title{
Trade-offs and synergies between carbon, forest diversity and forest products in Nepal community forests
}

THEMATIC SECTION

Forest Ecosystem Services

(FES)

\author{
EAK RANA ${ }^{1 *}$, RIK THWAITES ${ }^{1}$ AND GARY LUCK ${ }^{2}$ \\ ${ }^{1}$ Charles Sturt University - School of Environmental Sciences, Elizabeth Mitchell Drive, Thurgoona, Albury, \\ Nem South Wales 2640, Australia and ${ }^{2}$ Institute for Land, Water and Society, Charles Sturt University, PO Box \\ 789, Albury, Nem South Wales 2640, Australia
}

Date submitted: 8 October 2015; Date accepted: 24 September 2016; First published online 16 November 2016

\section{SUMMARY}

Reducing emissions from deforestation and forest degradation, the sustainable management of forests and the conservation and enhancement of forest carbon stocks in developing countries ('REDD+') aims to improve local livelihoods and conserve plant diversity while limiting carbon emissions. Yet trade-offs and synergies that exist between supporting livelihoods, protecting plant diversity and maintaining forest ecosystem services are poorly documented. We used forest inventory data and community-group records to assess trade-offs and synergies between carbon, plant diversity and forest products in 19 community forests managed under REDD+ in Nepal. Tradeoffs were prevalent for carbon, whereby community forests with relatively high carbon values had relatively low values for plant diversity or forest products provision, and vice versa. Synergies occurred between plant diversity and forest products provision (fuelwood and fodder), suggesting that forests with relatively high plant diversity values were also important for providing critical forest products to local communities. This study shows that conserving forests for carbon should not impinge greatly on the flow of forest resources to at least some local communities; however, promoting carbon storage will not necessarily protect plant diversity. These findings should help guide future REDD+ policy for community forests.

Keymords: carbon, plant diversity, REDD+, trade-offs, synergies, forest products

\section{INTRODUCTION}

Reducing emissions from deforestation and forest degradation, the sustainable management of forests and the conservation and enhancement of forest carbon stocks in developing countries ('REDD+') may protect non-carbon

\footnotetext{
${ }^{*}$ Correspondence: Dr. Eak Rana Tel: +61 260519850 e-mail: erana@csu.edu.au

Supplementary material can be found online at https://doi.org/ $10.1017 / \mathrm{S} 0376892916000448$
}

forest ecosystem services (ESs) (e.g. timber) while also improving carbon storage. For example, the implementation of REDD+ in Indonesia contributed to soil conservation through improved forest connectivity (Lu et al. 2012), while REDD+ has contributed to watershed conservation in subSaharan Africa and Costa Rica (Stringer et al. 2012).

Community forests (CFs) in developing countries, particularly Nepal, are considered successful models for conserving biodiversity while also providing forest products (e.g. timber and fuelwood) to local communities (Nagendra 2002; Shrestha et al. 2010). Yet REDD+, with its emphasis on protecting carbon, can undermine the original objectives of CFs. Various studies of preliminary REDD+ initiatives in CFs have suggested that forest resource access may be restricted and plant diversity lost when there is an overemphasis on protecting carbon (Pandey et al. 2014; Poudel et al. 2014).

The implementation of REDD+ may result in tradeoffs or synergies between ESs and plant diversity. For example, Maraseni et al. (2014) found that an increase in carbon corresponded with a decrease in forest products extraction in CFs in Nepal. Other authors (e.g. Chhatre \& Agrawal 2009; Visseren-Hamakers et al. 2012; Law et al. 2015) have demonstrated similar trade-offs between carbon, plant diversity and forest resources in forests managed under REDD+.

However, protecting carbon and plant diversity while still allowing extraction of forest products is possible under certain circumstances, leading to synergies in ES protection (Thompson et al. 2012). High plant diversity may enhance the resilience of forest ecosystems, generating greater biomass for carbon and forest products use (Pedro et al. 2014).

While REDD+ aims to improve local livelihoods and biodiversity conservation, in addition to increasing baseline carbon, information on trade-offs and synergies between carbon, plant diversity and local livelihoods is lacking, particularly in CFs (Martin et al. 2013). While several studies assess trade-offs and synergies at relatively large scales (Maes et al. 2012; Cademus et al. 2014), fewer studies have accounted for interactions between biodiversity, carbon and forest products at smaller scales relevant to the local implementation of REDD+ (Budiharta et al. 2014). Such knowledge should help forest managers limit trade-offs and maximize synergies for the delivery of ESs from forests (Locatelli et al. 2014). 


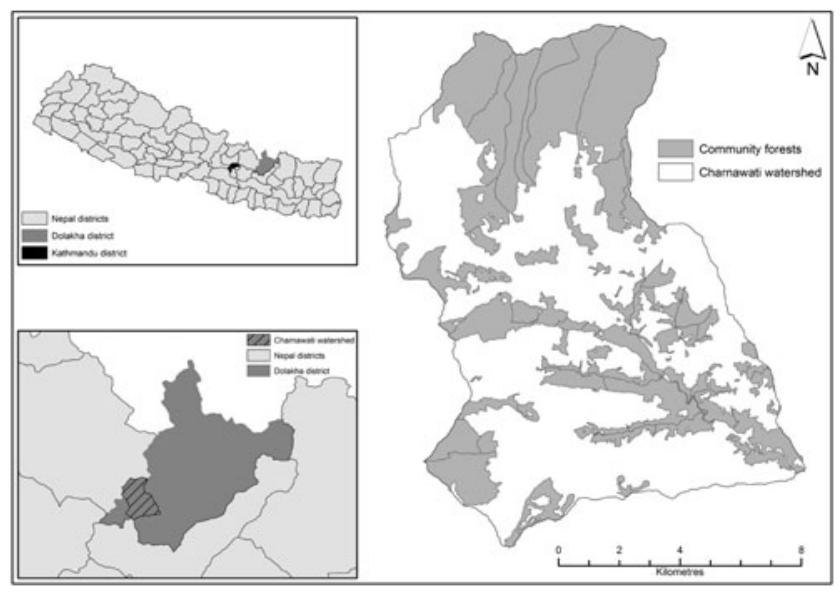

Figure 1 Diagrammatic map of the research site showing the locations of the Charnawati watershed and the 19 community forests.

Here, we examine the trade-offs and synergies between carbon, plant diversity and forest products that are critical to the livelihoods of local people of the Charnawati watershed of Nepal, managed under a REDD+ pilot. The implementation of REDD+ in Nepal was pioneered in the Charnawati, which also represents a showcase of the application of community forestry in the country. Forest products from CFs are critical sources of subsistence for local people in and around Charnawati, which serves as a valuable case study for developing forest management strategies that maximize the protection of plant diversity and carbon while ensuring the ongoing access of local communities to forest products.

The objectives of this study were to identify CFs where positive (mutually high-value) or negative (mutually lowvalue) synergies exist between carbon, plant diversity (i.e. plant species diversity and stem density) and forest products extraction (i.e. timber, fuelwood and fodder), as well as to identify CFs where trade-offs exist (i.e. have high values for one forest characteristic [e.g. timber] but low values for another [e.g. carbon]) between these attributes.

\section{METHODS}

\section{Study area}

This study was conducted in $19 \mathrm{CFs}$ in Charnawati watershed (652-3238 m altitude), Nepal (Fig. 1; Table 1), managed under a REDD+ pilot since 2009. Activities under REDD+ include annual carbon monitoring, capacity building and incentives distribution to $\mathrm{CF}$ managers. The CFs are generally semi-natural, and forest management activities include enrichment plantation, selective thinning, regulated grazing and harvesting of forest products - mainly timber, fuelwood and fodder/grass (hereafter fodder). Collectively, the CFs encompass diverse vegetation types such as sal (Shorea robusta) and chir pine (Pinus roxburghii) at lower altitudes and rhododendron (Rhododendron species) and oak (Quercus species) at higher altitudes.
The duration for which forests have been managed as CFs by local communities varies, and forests are managed by diverse user groups with different ethnicities, needs and socio-economic statuses. To assist in data interpretation, we classified the CFs into high $(\geq 2000 \mathrm{~m})$ or low altitude $(<2000$ $\mathrm{m}$ ); long duration of management (local CF management began before or at $2000 \mathrm{CE}$ ) or short duration of management (forest management began after $2000 \mathrm{CE}$ ); and small $(\leq 1.0$ ha of forest per household) or large ( $>1.0$ ha of forest per household) (Table 1).

\section{Data collection and analysis}

Vegetation data for carbon and plant diversity were collected through the International Centre for Integrated Mountain Development (ICIMOD) database, which was compiled from forest inventories conducted in February-April 2013. These data included the height and diameter at breast height (dbh) of trees and saplings, the number of seedlings and shrubs and grasses (not including ferns, mosses and lichens) collected from 112 composite plots of $250 \mathrm{~m}^{2}$ distributed across $19 \mathrm{CFs}$. A stratified random sampling design was used, whereby forests were stratified into dense ( $\geq 70 \%$ canopy density) and sparse ( $<70 \%$ canopy density) strata, using a geographic information system (ArcGIS) with Geo-eye satellite images captured in November 2009 (Subedi et al. 2010).

Forest products (i.e. annual harvest of timber $\left[\mathrm{m}^{3}\right]$, fuelwood [ $\mathrm{kg}]$ and fodder $[\mathrm{kg}]$ ) data for 2013 were collected from the logbooks and meeting minutes of $\mathrm{CF}$ groups during field visits to Nepal in July-October 2013. We reviewed annual data on the extraction of forest products from the start of the REDD+ project (i.e. 2009-2013), and we used data from 2013 as this represented the change in forest characteristics over a 4-year period and coincided with the end of the REDD+ pilot in the study area. These data were verified through meetings with key members of the executive committee.

\section{Carbon stock, plant diversity and forest product extraction}

Per ha carbon included five carbon pools: above- and belowground tree carbon; saplings and shrubs; herbs and grasses; leaf litter; and soil organic carbon. Aboveground tree and sapling carbon levels were calculated using the equation from Chave et al. (2005, p. 92) for moist forest types (Supplementary Material 1; available online).

We used a Nepal-specific biomass equation developed by Tamrakar (2000) to estimate the aboveground sapling (1-5 cm dbh) biomass (eqn (1)):

$$
\log (\mathrm{AGSB})=\mathrm{a}+\mathrm{b}(\log [\mathrm{D}])
$$

where AGSB $=$ aboveground sapling biomass $(\mathrm{kg}), \log =$ natural $\log , \mathrm{a}=$ intercept of the allometric relationship for saplings, $b=$ slope of the allometric relationship for saplings and $\mathrm{D}=$ overbark $\mathrm{dbh}(\mathrm{cm})$. 
Table 1 Main characteristics of community forests included in our study.

\begin{tabular}{rlcccl}
\hline \hline Forest number & Community forest & Altitude & Time in management & Forest size & Main vegetation type \\
\hline 1 & Barkhedandapari & Low & Long & Small & Chilaune, Castanopsis, chir pine \\
2 & Bhakare & Low & Short & Small & Chir pine \\
3 & Bhitteri & High & Long & Large & Oak, rhododendron, thingure salla \\
4 & Charnawati-1 & High & Long & Large & Oak, rhododendron, bluepine \\
5 & Charnawati-2 & Low & Long & Small & Sal, chir pine \\
6 & Chyasebhagabati & High & Long & Small & Alder, chir pine, chilaune \\
7 & Dhandesinghdevi & High & Short & Large & Rhododendron, patesalla, Castanopsis, \\
8 & Eklepakha & High & Long & Small & Chilaune, Castanopsis, bluepine \\
9 & Harisiddhimai & Low & Long & Small & Chilaune, Castanopsis, chir pine \\
10 & Jugedarkha & High & Short & Small & Rhododendron, thingure salla, bluepine \\
11 & Kopila & Low & Long & Large & Chilaune, alder, kalikath, rhododendron \\
12 & Majhkharkalisepani & High & Long & Large & Oak, rhododendron, patesalla \\
13 & Mathani & Low & Long & Small & Alder, bluepine, chilaune \\
14 & Napkeyanmara & High & Long & Large & Alder, bluepine, rhododendron, Castanopsis \\
15 & Setidevidadar & High & Short & Large & Oak, rhododendron \\
16 & Shivajungbhumethan & Low & Short & Small & Alder, chilaune \\
17 & Sitakunda & Low & Long & Small & Chir pine, sal \\
18 & Thangsadeurali & High & Long & Small & Oak, thingure salla, rhododendron, patesalla \\
19 & Thumkadanda & High & Short & Small & Rhododendron, bluepine, patesalla \\
\hline \hline
\end{tabular}

The biomass of herbs, litter and grasses was calculated using eqn (2):

$$
\mathrm{LHG}=\frac{\mathrm{W}_{\text {field }}}{\mathrm{A}} \frac{\mathrm{W}_{\text {subsample,dry }}}{\mathrm{W}_{\text {subsample,wet }}} \times 10
$$

where LHG = biomass of litter, herbs and grasses (tonnes $\left.\mathrm{ha}^{-1}\right), \mathrm{W}_{\text {field }}=$ weight of fresh field sample of litter, herbs and grasses $(\mathrm{g})$ within an area of size $\mathrm{A}\left(\mathrm{m}^{2}\right), \mathrm{W}_{\text {subsample, } d r y}=$ weight of oven-dried subsample of litter, herbs and grasses ( $g$ ) and $\mathrm{W}_{\text {subsample, met }}=$ weight of fresh field sample of litter, herbs and grasses $(\mathrm{g})$.

We calculated belowground biomass using a root:shoot ratio, whereby root parts are estimated to contain $20 \%$ of total aboveground biomass (MacDicken 1997, p. 84). Total biomass was converted into carbon by multiplying the biomass by the standard value of 0.47 (IPCC 2006). The soil carbon data we used were calculated by ICIMOD in 2010, and we assume that this is representative of 2013 values given that soil carbon does not change substantially over such a short period under the same land-use practices (MacDicken 1997; Martin et al. 2013).

Per ha timber $\left(\mathrm{m}^{3}\right)$ harvested was calculated from the total quantity of timber harvested from each $\mathrm{CF}$ divided by the area of the CF. Timber in CFs is generally harvested using selective logging of standing trees and from fallen trees. The location, tree species to harvest, annual harvestable quantity and the quantity assigned to local forest users are defined in the CF group's forest operational plans. Most of the harvested tree is used for timber, while tree tops and branches are used for fuelwood. Fuelwood is generally extracted from a combination of non-merchantable green and dried wood products such as fallen twigs, stumps and branches. Fodder contains leaves, branches and grass. The per ha annual harvest of fuelwood or fodder $(\mathrm{kg})$ for each $\mathrm{CF}$ was calculated by dividing the total quantity of fuelwood and fodder harvested (total number of full and half-head loads [a full head-load is considered to be $35 \mathrm{~kg}]$ ) by the area of the respective CF.

Plant species diversity was estimated using the ShannonWiener diversity index (H') (Magurran 2004). We calculated stem density by counting the number of trees, saplings and seedlings in the survey plots, whereby the average number of stems per plot in each CF was calculated by dividing the total number of stems by the total number of plots. The per ha stem density in each CF was then calculated by multiplying the density of stems in plots by 40 .

\section{Trade-offs and synergies between carbon, plant diversity and forest products}

We aimed to identify CFs that had high or low values for multiple ESs or between an ES and plant diversity (positive or negative synergies, respectively), or had low values for one ES and high values for another, or a high/low outcome for an ES and plant diversity (i.e. a trade-off). We first analysed pair-wise associations among variables using Spearman's rank order correlation. The strengths of association between variables were classified into five categories based on the correlation coefficient following Dancey and Reidy (2007): zero (0), weak (0.01-0.3), moderate (0.31-0.60), strong (0.61$0.90)$ and perfect $(0.91-1.00)$.

The purpose of this initial analysis was to determine if, when examining trends across all forests, there were strong synergies (large positive correlation coefficients) or trade-offs (large negative correlation coefficients) across the CFs; that is, for example, did forests with large carbon values consistently have large plant diversity values (positive synergies) or did forests 


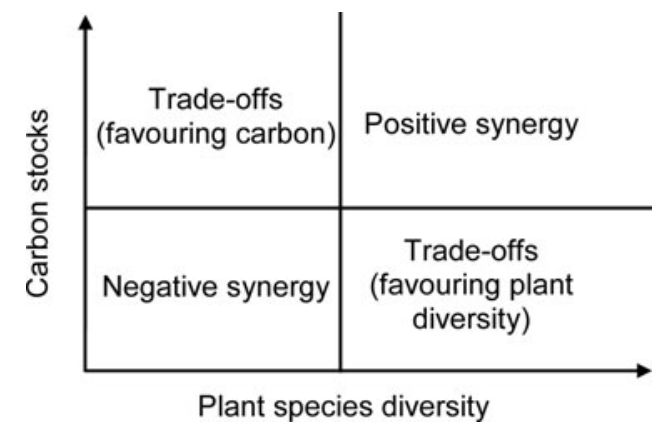

Figure 2 Framework for assessing the trade-offs or synergies between two variables in the context of carbon and plant species diversity. Solid black lines represent the median values. The top left quadrant represents forests with high carbon values (above the median value for carbon) but low values for plant species diversity (below the median value for plant species diversity).

with large carbon values consistently have small plant diversity values (trade-offs)? Importantly, weak correlation coefficients in this analysis are indicative of a much more complex relationship between forest characteristics, suggesting that only some individual forests may have mutually high values of, for example, carbon and forest products, while other forests may have low values of one characteristic, but high values of the other. Hence, weak and strong correlation coefficients uncover fundamentally different, but equally important, dynamics across the group of forests.

We then analysed trade-offs and synergies in ESs and plant diversity using methods described in Luck et al. (2009). First, we standardized the numerical values (Supplementary Material 2) of carbon, plant diversity and forest products using Z-scores so that the values of each attribute had a mean of zero and a standard deviation of one. Then we calculated the median value for each attribute, which was used as the threshold value to determine if values were 'high' or 'low' (i.e. above or below the median value, respectively). Finally, we plotted values in pair-wise comparisons to identify trade-offs or synergies for any given CF. For example, in a pair-wise comparison of values for carbon and plant diversity, a given forest may have high values for both (positive synergy), low values for both (negative synergy), a high value for carbon but a low value for plant diversity (a trade-off favouring carbon) or a low value for carbon but a high value for plant diversity (a trade-off favouring plant diversity) (Fig. 2). A number from 1 to 19 was assigned to each CF (Table 1), and these numbers were used as labels in the scatter plots showing trade-offs and synergies.

\section{RESULTS}

\section{Correlations between carbon, plant diversity and forest products}

There were mostly weak correlations across CFs for carbon, plant diversity attributes and forest products extraction (Table 2). Plant diversity was significantly positively correlated with fuelwood, suggesting forest user groups get this resource mostly from diverse CFs. In general, however, plant diversity attributes were weakly negatively correlated with forest product extraction.

\section{Trade-offs and synergies between carbon, plant diversity and forest products}

Trade-offs were particularly prevalent for carbon, in that a $\mathrm{CF}$ would have a high carbon value and a low value for plant diversity attributes or forest products, or vice versa (Table 3). This was also true for stem density, where tradeoffs existed with timber, fuelwood and fodder. Synergies were more prevalent for plant species diversity and fuelwood and fodder. This suggests that CFs with high plant diversity values were also important for providing some critical forest products to local communities.

CFs 2 (Bhakare) and 17 (Sitakunda) (both low-altitude and small forests) consistently experienced trade-offs favouring carbon over all plant diversity attributes (Fig. 3); that is, they had higher than median carbon values, but lower than median plant species diversity and stem density values. Conversely, CFs 8 (Eklepakha), 12 (Majhakharkalisepani) and 19 (Thumkadanda) (high-altitude and mostly small forests) had higher than median plant diversity values, but lower carbon values. Positive synergies were consistently recorded for CFs 3 (Bhitteri) and 14 (Napkeyanmara) (high-altitude, long duration of management and large forests). This suggests that forest size may be important for whether a trade-off or synergy occurs between carbon and plant diversity.

A positive synergy between carbon and all forest products was recorded for CF 13 (Mathani) (a low-altitude and small forest), whereas consistent trade-offs favouring all forest products were recorded for CFs 18 and 19 (high-altitude and small forests) and favouring carbon for CF 4 (Charnawati-1) (a high-altitude and large forest) (Fig. 3). This suggests that small CFs at higher altitudes may be relatively more important for providing forest products, while large forests around the same altitude are important for protecting carbon.

CFs 13 and 19 (small forests) had positive synergies between plant species diversity and all forest products, while CF 4 (a high-altitude and large forest) had negative synergies (Fig. 4). CF 18 showed trade-offs favouring all forest products over plant species diversity. CF 19 consistently had positive synergies between stem density and all forest products, while consistent trade-offs favouring all forest products over stem density existed for CFs 13 and 18 (low-altitude and small forests). This implies that plant species diversity and stem density had inconsistent trade-offs and synergies with forest products.

\section{DISCUSSION}

\section{Relationships between carbon and plant diversity}

Forest carbon was weakly negatively correlated with plant diversity. Higher plant diversity may coincide with higher 
Table 2 Results of Spearman's rank order correlations between carbon, plant diversity and forest products. ${ }^{*}$ Correlation is significant at the 0.05 significance level (two-tailed).

\begin{tabular}{lcc}
\hline \hline Carbon, plant diversity attributes and forest products & Correlation $\left(r_{s}\right)$ mith p-value & Strength of association \\
\hline Carbon and plant species diversity & $-0.14(p=0.54)$ & Weak \\
Carbon and stem density & $-0.28(p=0.24)$ & Weak \\
Carbon and timber & $0.01(p=0.98)$ & Weak \\
Carbon and fuelwood & $-0.06(p=0.81)$ & Weak \\
Carbon and fodder & $0.05(p=0.83)$ & Weak \\
Plant species diversity and timber & $-0.16(p=0.50)$ & Weak \\
Plant species diversity and fuelwood & $0.48^{*}(p=0.03)$ & Moderate \\
Plant species diversity and fodder & $0.26(p=0.27)$ & Weak \\
Stem density and timber & $-0.37(p=0.11)$ & Moderate \\
Stem density and fuelwood & $-0.22(p=0.34)$ & Weak \\
Stem density and fodder & $-0.26(p=0.27)$ & Weak \\
\hline \hline
\end{tabular}

Table 3 The number of community forests having trade-offs and synergies between carbon, plant diversity and forest products.

\begin{tabular}{|c|c|c|c|c|c|c|}
\hline Forest attributes & $\begin{array}{l}\text { Trade-offs } \\
\text { (higher } \\
\text { values of } A \text { ) }\end{array}$ & $\begin{array}{l}\text { Trade-offs } \\
\text { (higher } \\
\text { values of } B \text { ) }\end{array}$ & $\begin{array}{l}\text { Community } \\
\text { forests with } \\
\text { trade-offs }\end{array}$ & $\begin{array}{l}\text { Positive } \\
\text { synergy }\end{array}$ & $\begin{array}{l}\text { Negative } \\
\text { synergy }\end{array}$ & $\begin{array}{l}\text { Community } \\
\text { forests mith } \\
\text { synergies }\end{array}$ \\
\hline (A) Carbon and (B) plant species diversity & 5 & 5 & 10 & 5 & 4 & 9 \\
\hline (A) Carbon and (B) stem density & 6 & 6 & 12 & 4 & 3 & 7 \\
\hline (A) Carbon and (B) timber & 5 & 5 & 10 & 5 & 4 & 9 \\
\hline (A) Carbon and (B) fuelwood & 6 & 6 & 12 & 4 & 3 & 7 \\
\hline (A) Carbon and (B) fodder & 4 & 4 & 8 & 6 & 5 & 11 \\
\hline (A) Plant species diversity and (B) timber & 6 & 6 & 12 & 4 & 3 & 7 \\
\hline (A) Plant species diversity and (B) fuelwood & 3 & 3 & 6 & 7 & 6 & 13 \\
\hline (A) Plant species diversity and (B) fodder & 4 & 3 & 7 & 6 & 6 & 12 \\
\hline (A) Stem density and (B) timber & 5 & 5 & 10 & 5 & 4 & 9 \\
\hline (A) Stem density and (B) fuelwood & 6 & 6 & 12 & 4 & 3 & 7 \\
\hline (A) Stem density and (B) fodder & 6 & 6 & 12 & 4 & 3 & 7 \\
\hline
\end{tabular}

carbon stocks in some natural forests (Day et al. 2014), but there was no evidence of this in our study. This may be due to the prevalence of plant species such as chir pine and alder, which have relatively low carbon storage capacities in the research site. In some cases, lower carbon stocks can exist even in highly diverse forests if the dominant tree species has a low carbon storage capacity (Kirby \& Potvin 2007; Baral et al. 2009).

Mandal et al. (2013) and Kimaro and Lulandala (2013) found negative relationships between carbon and plant species diversity. Forest thinning through selective removal of large trees may reduce carbon without impacting negatively on plant species diversity (Widenfalk \& Weslien 2009), and the majority of CFs in our study apply thinning to extract large trees.

We found a weak negative association between carbon and stem density, implying that the size and average carbon storage capacity of particular trees is more important to carbon stocks than simply the number of plants present. Pandey et al. (2014) estimated the maximum average per ha carbon storage capacity of chir pine, Schima-Castanopsis, RhododendronQuercus and sal trees in the research site as 91.4, 87.9, 102.9 and 121.2 tonnes, respectively. Murphy et al. (2013) found non- significant relationships between carbon and stem density, while Wang et al. (2011) recorded less carbon in forests with greater stem density, mainly due to the prevalence of smaller trees. It appears that the growth stage of forests may determine the carbon-stem density relationship.

In terms of trade-offs and synergies, there were varying results across CFs and forest attributes. Positive synergies between carbon and plant diversity existed mostly in highaltitude and large CFs. These forests are therefore important for maintaining plant diversity, while also storing relatively high levels of carbon, and large forests may buffer adverse impacts on plant species diversity. Trade-offs favouring carbon over plant species diversity occurred mostly in small forests located at low elevation. Low-altitude (i.e. subtropical) forests support plant species with higher carbon storage capacities (Baral et al. 2009), although overall plant species diversity is relatively low.

\section{Relationships between carbon and forest products}

There was a weak positive correlation between carbon and the amount of timber and fodder extracted from forests. A higher level of forest products extraction generally corresponds with 

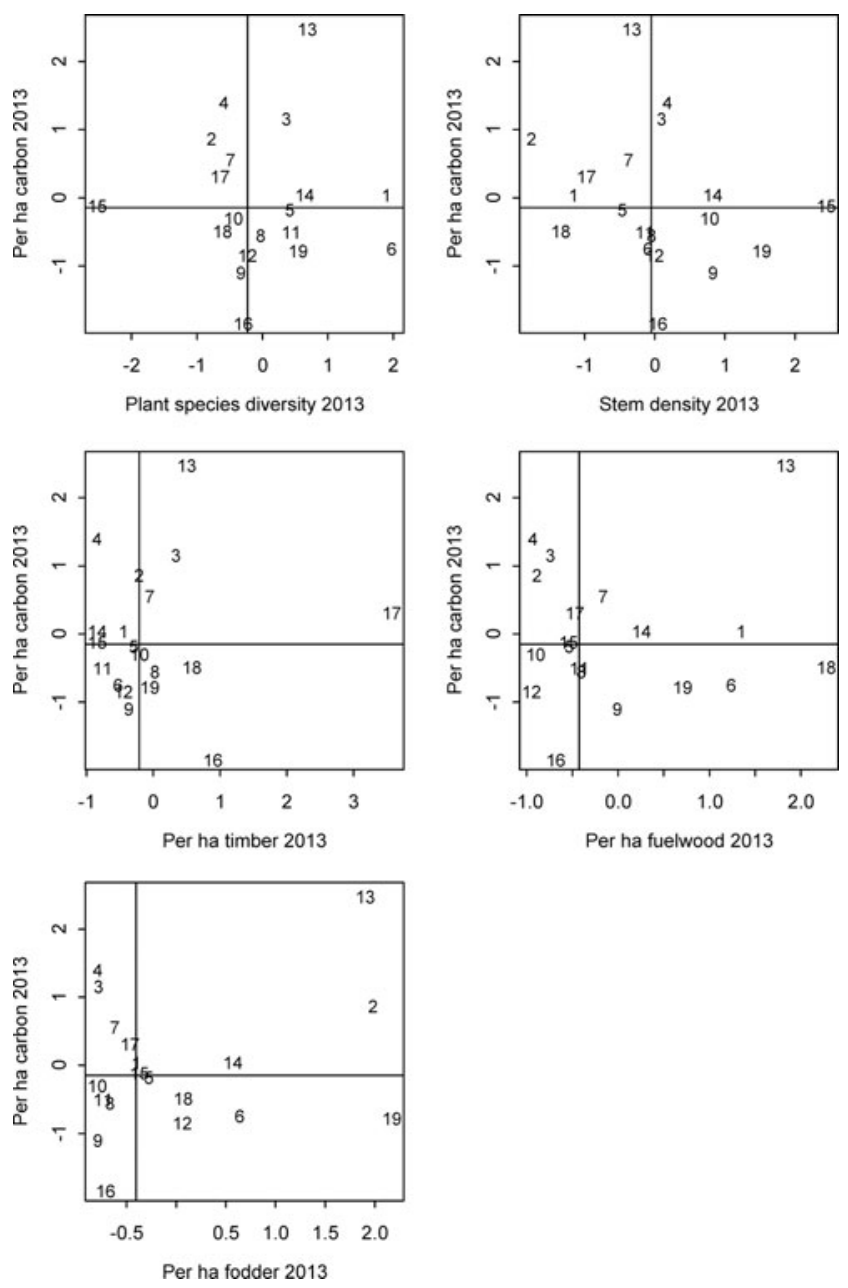

Figure 3 Community forests with trade-offs and synergies between carbon, plant diversity attributes and forest products. Numerical values along the $\mathrm{x}$ - and $\mathrm{y}$-axes are $\mathrm{Z}$-scores. Forests (represented by forest number) in the top left and bottom right quadrants indicate trade-offs, while forests in the top right and bottom left quadrants indicate positive and negative synergies, respectively.

lower carbon stocks (Schwenk et al. 2012). However, there was no evidence of this in our study for timber or fodder. A positive relationship between carbon and timber extracted could be due to the application of sustainable harvesting techniques by local people. Adoption of reduced-impact logging for timber extraction may not reduce carbon (Nghiem 2014). In the study area, timber is extracted from selected tree species based on an annual allowable harvesting limit in the majority of CFs. This means that timber extraction may not impede overall forest carbon (Putz et al. 2012). Also, the application of postharvest restoration and planting can enhance carbon despite the removal of timber (Perez-Garcia et al. 2005).

Fodder extraction in this study area may not negatively impact carbon storage potential because fodder is generally extracted from leaves and branches without felling standing trees. However, further assessment is required to test this relationship owing to limitations in the allometric equation
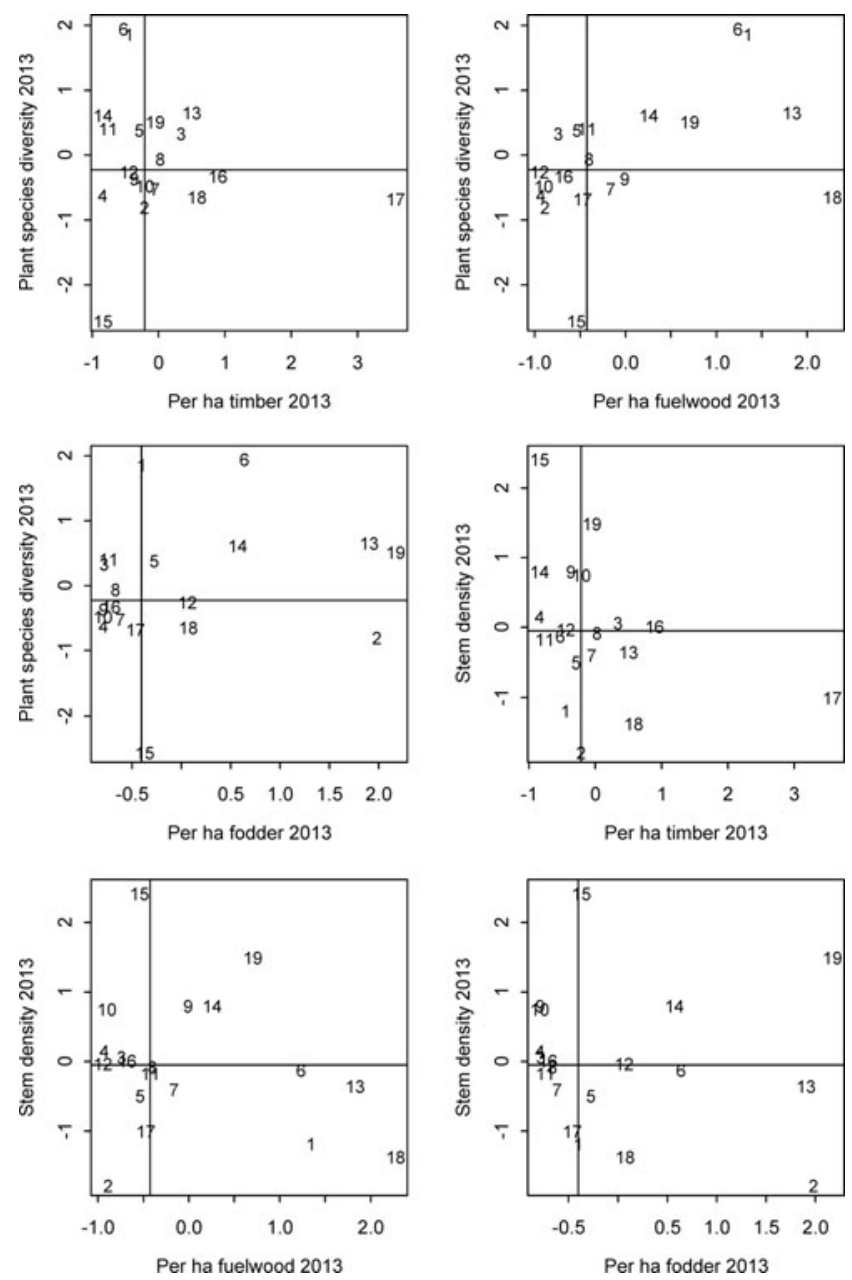

Figure 4 Community forests with trade-offs and synergies between plant diversity attributes and forest products. Numerical values along the $\mathrm{x}$ - and $\mathrm{y}$-axes are $\mathrm{Z}$-scores. Forests (represented by forest number) in the top left and bottom right quadrants indicate trade-offs, while forests in the top right and bottom left quadrants indicate positive and negative synergies, respectively.

as applied in Nepal. Because the equation is based only on tree height and dbh, it does not account for other changes in tree biomass (biomass discount factor), such as removal of leaves and branches. Barshila et al. (2013) and Singh and Sundriyal (2009) also found that the extraction of fodder has a small effect on carbon. We found a very weak negative relationship between carbon and fuelwood. While fuelwood is extracted throughout most of the year in the majority of $\mathrm{CFs}$, this currently does not appear to be having a significant negative impact on carbon. However, this needs to be carefully monitored in future years.

Trade-offs and synergies between carbon and forest products extraction varied across CFs. Trade-offs favouring carbon over all forest products occurred mostly in larger forests under short and long durations of management, and at low and high altitudes. This demonstrates the resilience of large forests to local community demands, but this 
resilience is dependent on future levels of demand, the management strategies implemented to ensure sustainable harvesting practices and changes in natural disturbances such as insect and disease outbreaks and forest fires.

While the relationships between carbon and forest product extraction reflect the level of forest dependency of local people, they are also influenced by access to alternatives to forest products (e.g. private sources), forest product distribution rules and local perceptions of the importance of protecting carbon (Bhattarai et al. 2012; Bluffstone et al. 2013). For example, Chhatre and Agrawal (2009) found positive synergies between carbon and forest product extraction in larger CFs when sustainable resource use practices were adopted. Similarly, Chand et al. (2015) found a positive relationship between forest products and carbon, and the authors argued that managing CFs for certain forest products may enhance carbon.

\section{Relationships between plant diversity attributes and forest products}

Plant species diversity was positively related to the harvesting of fuelwood and fodder, but not timber. This suggests that a greater amount of fuelwood and fodder was extracted from more diverse forests. Extraction of forest products from green and standing trees is restricted in the majority of CFs in the research site. Fuelwood is extracted mainly from branches, dead twigs and stumps, while fodder is extracted from leaves and branches without felling standing trees. Removal of these resources likely has a small effect on the number and diversity of living plants (Måren et al. 2014), although over the long term it may adversely impact overall plant diversity. Shrestha et al. (2013) in Nepal observed no impact on the plant diversity of the fodder extraction from tree branches and leaves, and found that the removal of fodder up to a certain amount (i.e. intermediate disturbance) may actually result in an opening in the forest canopy, which can lead to greater plant species diversity.

There was a weak negative correlation between timber extraction and plant species diversity. In our study area, timber is generally extracted from live-standing trees of specific tree species (e.g. sal and chir pine in low-altitude forests and thingure salla [Tsuga dumosa] and bluepine [Pinus mallichiana] in high-altitude forests) with certain qualities such as strength, durability and straightness. Repeated removal of live-standing trees may eventually lead to local declines of particular plant species (Hall et al. 2003). Timber extraction may also have negative effects on plant diversity due to physical damage to the natural regeneration of seedlings during timber harvesting (Tavankar \& Bonyad 2015). This is highly relevant to this research site since timber extraction is generally performed manually (involving people felling and removing logs).

CFs that had trade-offs favouring timber over plant diversity were mostly small forests at high altitude. The prevalence of such trade-offs in high-altitude forests may be due to their slow growth and the fact that the introduction of new plant species is often unsuccessful owing to unsuitable ecological conditions. The positive synergies in some CFs between plant diversity and fuelwood or fodder may be the result of forest users planting multipurpose plant species that provide resources while also increasing overall plant diversity. This was observed mostly in management of long duration and larger forests. Such activities may occur in larger CFs because there is enough space for planting multiple tree species, while greater forest management experience may lead to more effective management strategies.

Some studies have shown a decline in stem density in forests with the removal of fuelwood and fodder from live-standing trees (Jiang et al. 2015; Tavankar \& Bonyad 2015), but there was little evidence of this occurring in our study area. Stem density is generally associated with the intensity of silviculture practices such as thinning (Thomas et al. 1999), which is adopted by almost every $\mathrm{CF}$ in Charnawati to extract fuelwood and timber.

\section{CONCLUSION AND POLICY IMPLICATIONS}

Both trade-offs and synergies occurred across CFs for carbon, plant diversity and forest products. Trade-offs were particularly prevalent between carbon and plant diversity and certain forest products, while synergies existed between plant diversity, fuelwood and fodder.

The patterns of trade-offs and synergies varied across CFs depending on forest size, time in management and altitude, and these factors reflect differences in forest vegetation types, management practices and local needs. For example, larger forests in high-altitude regions have high values for carbon and plant diversity, with greater capacity to withstand the pressure of forest products removal. This suggests more broadly that larger forests could be targeted to provide local communities with resources without undermining carbon storage potential or plant diversity conservation. Despite being small, lowaltitude forests had high carbon values, likely owing to the presence of fast-growing tree species located in a sub-tropical climatic zone with deep and fertile soils (Maraseni \& Pandey 2014). This suggests that smaller forests elsewhere may play an important role in carbon storage, and could be protected primarily for this purpose, rather than to provide forest products.

The results indicate that within Charnawati and in similar regions globally, an integrated approach to forest management that includes sustainable harvesting of forest products and livelihood improvement activities outside of forests is required to protect carbon, plant diversity and forest resources. The conservation of biodiversity and safeguarding the rights of local people are central to current REDD+ debates, and also need to be integrated into existing local forest management practices as directed by their operational plans. Compensating local people for growing trees in private forests, introducing alternative fuel sources for cooking and implementing nonforest-based income-generating activities targeting land-poor forest users can enhance carbon and conserve biodiversity. 
Without REDD+-influenced management of forests, we suggest that forest managers will have fewer incentives to limit the extraction of forest products, leading to less protection of carbon and plant diversity. It is also likely that forest management will not account appropriately for the different values of forests (e.g. natural, social and economic), and there would be less chance of integrated management across a suite of forests.

This study includes the plant diversity measures that are most relevant to changes in carbon in $\mathrm{CFs}$, but we acknowledge that other biodiversity measures such as fauna diversity may lead to different synergy and trade-off relationships between these forest characteristics. Nevertheless, this study provides a foundation upon which further systematic assessment of trade-offs and synergies can be conducted for other forest ESs in $\mathrm{CFs}$ or other management regimes in different regions. The results of this study should help policy makers and planners in Nepal and other countries to design improved REDD+ initiatives and forest policies that generate multiple benefits for local communities, improve plant diversity conservation and reduce carbon emissions.

\section{ACKNOWLEDGEMENTS}

We thank Charles Sturt University, Faculty of Science for scholarship and the International Centre for Integrated Mountain Development (ICIMOD) for sharing their forest inventory data. The contribution of Gary Luck was supported by an Australian Research Council Future Fellowship FT0990436. We also acknowledge our three anonymous reviewers for their valuable and useful comments and suggestions to improve the manuscript.

\section{CONFLICT OF INTEREST}

The authors declare that there are no conflicts of interest regarding the publication of this manuscript.

\section{ETHICAL STANDARDS}

This article does not contain any studies with animal subjects. Informed consent was obtained from all residents of the local communities in Nepal that contributed information to our study. Interviews with local residents were conducted under the guidance and approval of the Human Research Ethics Committee of Charles Sturt University (Approval \#410/2013/07).

\section{Supplementary Material}

To view supplementary material for this article, please visit https://doi.org/10.1017/S0376892916000448

\section{References}

Baral, S., Malla, R. \& Ranabhat, S. (2009) Above-ground carbon stock assessment in different forest types of Nepal. Banko fanakari 19: $10-14$.
Barshila, I., Devkota, N. \& Barsila, S. (2013) Perception of smallholder farmers on fodder tree utilization and management for livestock production in the mid-hills of Nepal. Fournal of Animal Production Advances 3: 290-300.

Bhattarai, T.P., Skutsch, M., Midmore, D.J. \& Rana, E. (2012) The carbon sequestration potential of community based forest management in Nepal. The International Journal of Climate Change Impacts and Responses 3: 233-253.

Bluffstone, R., Robinson, E. \& Guthiga, P. (2013) REDD+ and community-controlled forests in low-income countries: any hope for a linkage? Ecological Economics 87: 43-52.

Budiharta, S., Meijaard, E., Erskine, P.D., Rondinini, C., Pacifici, M. \& Wilson, K.A. (2014) Restoring degraded tropical forests for carbon and biodiversity. Environmental Research Letters 9: 12.

Cademus, R., Escobedo, F.J., McLaughlin, D. \& Abd-Elrahman, A. (2014) Analyzing trade-offs, synergies, and drivers among timber production, carbon sequestration, and water yield in Pinus elliotii forests in southeastern USA. Forests 5: 1409-1431.

Chand, N., Kerr, G.N. \& Bigsby, H. (2015) Production efficiency of community forest management in Nepal. Forest Policy and Economics 50: 172-179.

Chave, J., Andalo, C., Brown, S., Cairns, M., Chambers, J., Eamus, D. et al. (2005) Tree allometry and improved estimation of carbon stocks and balance in tropical forests. Oecologia 145: 87-99.

Chhatre, A. \& Agrawal, A. (2009) Trade-offs and synergies between carbon storage and livelihood benefits from forest commons. Proceedings of the National Academy of Sciences, 106: 17667-17670.

Dancey, C.P. \& Reidy, J. (2007) Statistics mithout Maths for Psychology. Harlow, UK: Pearson Education.

Day, M., Baldauf, C., Rutishauser, E. \& Sunderland, T.C. (2014) Relationships between tree species diversity and above-ground biomass in Central African rainforests: implications for REDD. Environmental Conservation 41: 64-72.

Hall, J.S., Harris, D.J., Medjibe, V. \& Ashton, P.M.S. (2003) The effects of selective logging on forest structure and tree species composition in a Central African forest: implications for management of conservation areas. Forest Ecology and Management 183: 249-264.

IPCC (2006) 2006 IPCC guidelines for national greenhouse gas inventories. In: National Greenhouse Gas Inventories Programme, ed. H.S. Eggleston, L. Buendia, K. Miwa, T. Nagara \& K. Tanabe, pp. 4-48. Hayama, Japan: Institute of Global Environmental Strategies.

Jiang, J., Lu, Y., Pang, L., Liu, X., Cai, D. \& Xing, H. (2015) Shortterm effects of the management intensities on structure dynamic in monoculture forests of southern subtropical China. Tropical Conservation Science 8: 187-200.

Kimaro, J. \& Lulandala, L. (2013) Human influences on tree diversity and composition of a coastal forest ecosystem: the case of Ngumburuni forest reserve, Rufiji, Tanzania. International fournal of Forestry Research 2013: 305874.

Kirby, K.R. \& Potvin, C. (2007) Variation in carbon storage among tree species: implications for the management of a small-scale carbon sink project. Forest Ecology and Management 246: 208-221.

Law, E.A., Bryan, B.A., Meijaard, E., Mallawaarachchi, T., Struebig, M. \& Wilson, K.A. (2015) Ecosystem services from a degraded peatland of Central Kalimantan: implications for policy, planning, and management. Ecological Applications 1: 70-87.

Locatelli, B., Imbach, P. \& Wunder, S. (2014) Synergies and tradeoffs between ecosystem services in Costa Rica. Environmental Conservation 41: 27-36. 
Lu, H., Yan, W., Qin, Y. \& Liu, G. (2012) More than carbon stocks: a case study of ecosystem-based benefits of REDD+ in Indonesia. Chinese Geographical Science 22: 390-401.

Luck, G.W., Chan, K. \& Fay, J.P. (2009) Protecting ecosystem services and biodiversity in the world's watersheds. Conservation Letters 2: 179-188.

MacDicken, K.G. (1997) A Guide to Monitoring Carbon Storage in Forestry and Agroforestry Projects. Arlington, VA: Winrock International Institute for Agricultural Development.

Maes, J., Paracchini, M.L., Zulian, G., Dunbar, M.B. \& Alkemade, R. (2012) Synergies and trade-offs between ecosystem service supply, biodiversity, and habitat conservation status in Europe. Biological Conservation 155: 1-12.

Magurran, A.E. (2004) Measuring Biological Diversity (2nd ed.). Oxford, UK: Blackwell Science Ltd.

Mandal, R.A., Dutta, I.C., Jha, P.K. \& Karmacharya, S. (2013) Relationship between carbon stock and plant biodiversity in collaborative forests in Terai, Nepal. ISRN Botany, 2013: 625767.

Maraseni, T. \& Pandey, S. (2014) Can vegetation types work as an indicator of soil organic carbon? An insight from native vegetations in Nepal. Ecological Indicators 46: 315-322.

Maraseni, T.N., Neupane, P.R., Lopez-Casero, F. \& Cadman, T. (2014) An assessment of the impacts of the REDD+ pilot project on community forests user groups (CFUGs) and their community forests in Nepal. Fournal of Environmental Management 136: 37-46.

Måren, I.E., Bhattarai, K.R. \& Chaudhary, R.P. (2014) Forest ecosystem services and biodiversity in contrasting Himalayan forest management systems. Environmental Conservation 41: 7383.

Martin, P.A., Newton, A.C. \& Bullock, J.M. (2013) Carbon pools recover more quickly than plant biodiversity in tropical secondary forests. Proceedings of the Royal Society B: Biological Sciences 280: 20132236.

Murphy, H.T., Bradford, M.G., Dalongeville, A., Ford, A.J. \& Metcalfe, D.J. (2013) No evidence for long-term increases in biomass and stem density in the tropical rain forests of Australia. Fournal of Ecology 101: 1589-1597.

Nagendra, H. (2002) Tenure and forest conditions: community forestry in the Nepal Terai. Environmental Conservation 4: 530 539.

Nghiem, N. (2014) Optimal rotation age for carbon sequestration and biodiversity conservation in Vietnam. Forest Policy and Economics 38: 56-64.

Pandey, S.S., Cockfield, G. \& Maraseni, T.N. (2014) Dynamics of carbon and biodiversity under REDD+ regime: a case from Nepal. Environmental Science E Policy 38: 272-281.

Pandey, S.S., Maraseni, T.N. \& Cockfield, G. (2014) Carbon stock dynamics in different vegetation dominated community forests under REDD+: a case from Nepal. Forest Ecology and Management 327: 40-47.

Pedro, M.S., Rammer, W. \& Seidl, R. (2014) Tree species diversity mitigates disturbance impacts on the forest carbon cycle. Oecologia 177: 619-630.

Perez-Garcia, J., Lippke, B., Comnick, J. \& Manriquez, C. (2005) An assessment of carbon pools, storage, and wood products market substitution using life-cycle analysis results. Wood and Fiber Science 37: 140-148.

Poudel, M., Thwaites, R., Race, D. \& Dahal, G.R. (2014) REDD+ and community forestry: implications for local communities and forest management - a case study from Nepal. International Forestry Reviem 16: 39-54.
Putz, F.E., Zuidema, P.A., Synnott, T. Peña-Claros, M., Pinard, M.A., Sheil, D. et al. (2012) Sustaining conservation values in selectively logged tropical forests: the attained and the attainable. Conservation Letters 5: 296-303.

Schwenk, W.S., Donovan, T.M., Keeton, W.S. \& Nunery, J.S. (2012) Carbon storage, timber production, and biodiversity: comparing ecosystem services with multi-criteria decision analysis. Ecological Applications 22: 1612-1627.

Shrestha, K.B., Måren, I.E., Arneberg, E., Sah, J.P. \& Vetaas, O.R. (2013) Effect of anthropogenic disturbance on plant species diversity in oak forests in Nepal, Central Himalaya. International Journal of Biodiversity Science, Ecosystem Services E Management 9: 21-29.

Shrestha, U.B., Shrestha, B.B. \& Shrestha, S. (2010) Biodiversity conservation in community forests of Nepal: rhetoric and reality. International Fournal of Biodiversity and Conservation 5: 98104.

Singh, N. \& Sundriyal, R. (2009) Fuelwood, fodder consumption and deficit pattern in central Himalayan village. Nature and Science 7: 85-88.

Stringer, L.C., Dougill, A.J., Mkwambisi, D.D., Dyer, J.C., Kalaba, F.K. \& Mngoli, M. (2012) Challenges and opportunities for carbon management in Malawi and Zambia. Carbon Management 3: 159173.

Subedi, B.P., Pandey, S.S., Pandey, A., Rana, E.B., Bhattarai, S., Banskota, T.R. et al. (2010) Forest Carbon Stock Measurement Guidelines for Measuring Carbon Stocks in Community-Managed Forests. Kathmandu, Nepal: Asia Network for Sustainable Agriculture and Bioresources (ANSAB).

Tamrakar, P.R. (2000) Biomass and Volume Tables with Species Description in Community Forest Management. Kathmandu, Nepal: Government of Nepal, Ministry of Forests and Soil Conservation, Natural Resource Management Sector Assistance Programme (NARMSAP), Tree Improvement and Silviculture Treatment.

Tavankar, F. \& Bonyad, A.E. (2015) Effects of timber harvest on structural diversity and species composition in hardwood forests. Biodiversitas 16: 1-9.

Thomas, S.C., Halpern, C.B., Falk, D.A., Liguori, D.A. \& Austin, K.A. (1999) Plant diversity in managed forests: understory responses to thinning and fertilization. Ecological applications $\mathbf{9}$ : 864-879.

Thompson, I., Ferreira, J., Gardner, T., Guariguata, M., Koh, L.P., Okabe, K. et al. (2012) Forest biodiversity, carbon and other ecosystem services: relationships and impacts of deforestation and forest degradation. In: Understanding Relationships between Biodiversity, Carbon, Forest and People: The Key to Achieving REDD+ Objectives, eds. J.A. Parrotta, C. Wildburger \& S. Mansourian, pp. 21-50. Vienna, Austria: International Union for Forest Research Organizations.

Visseren-Hamakers, I.J., McDermott, C., Vijge, M.J. \& Cashore, B. (2012) Trade-offs, co-benefits and safeguards: current debates on the breadth of REDD+. Current Opinion in Environmental Sustainability 4: 646-653.

Wang, W., Lei, X., Ma, Z., Kneeshaw, D.D. \& Peng, C. (2011) Positive relationship between aboveground carbon stocks and structural diversity in spruce-dominated forest stands in New Brunswick, Canada. Forest Science 57: 506-515.

Widenfalk, O. \& Weslien, J. (2009) Plant species richness in managed boreal forests - effects of stand succession and thinning. Forest Ecology and Management 257: 1386-1394. 